\title{
An Interview with Harold Bloom
}

\section{José Antonio Gurpegui Universidad de Alcalá}

José Antonio Gurpegui: What's the reason for writing a book about the Western Canon, particularly now?

Harold Bloom: Well, this brings one to the question of a national context: in fact people in American universities and colleges and in the secondary schools and in academies throughout the English-speaking world, are very much worried about canonical matters because a tremendous debate has been going on now for about the last twenty years or so, which in one very bad sense is settled: that the people who would argue for humanistic education, in English at least (the study of the traditional Western Canon, from Homer through Shakespeare, Cervantes and Tolstoy, down to Marcel Proust, say, or Samuel Beckett), we have been defeated. A traditional Western Canon is largely not studied anymore in American colleges, universities, preparatory schools, secondary schools, and this is true also in Australia, New Zealand, Canada, Great Britain, and so forth.

But the personal reason is really quite different, and had nothing to do with polemic. I am a literary critic in my middle sixties; I've been writing about literature, publishing on literature since 1957 . I've been a student of literature really from the time I was a very small boy; in any language I could teach myself to read. And I've written a number of books, and I just thought it was time that I write a kind of general study of literature, trying to see if I could isolate those qualities that in the end unify Shakespeare, Cervantes, Dante, Chaucer, Tolstoy, and so on, and trying to extend Walter Pater's notion of the aesthetic or Oscar Wilde's notion of the aesthetic to a kind of general defense of the aesthetic study of literature.

From a Spanish perspective, a number of things that I talk about the book in would not make much sense: thus my favorite sentence in the entire book must be totally incomprehensible to a Spanish reader, an Iberian reader. And that is the rather bitter and 
ironic sentence, which I quote verbatim from the book, "If multiculturalism meant Cervantes, then who could protest?" There is in the English-speaking countries, but particularly in the United States, a terrible movement in the academies called "multiculturalism," which holds that the racial, sexual, and class origin of a work of literature is far more important than any other aspect of a work of literature, and which insists that aesthetic value is merely a mask, or disguise, for, as they would say, sexist, racist, economic exploitative forces.

The plague of American universities and colleges, and indeed of all academic institutions now throughout the English-speaking world, are the extraordinary collection of what I would call "pseudo-Marxists" (because they are not Marxists), and "pseudo-feminists," "feministists" as I like to call them (because they are not really feminists), and the "pseudo-historicists," disciples of Foucault, who, in conjunction with multiculturalists and various kinds of so-called theoreticians, mostly of the French variety, have pretty much destroyed the traditional study of Western literature in the English-speaking world. I think this process has gone much further in the United States and Great Britain than it has in Spain, which is after all ethnically a homogenous country, so that multiculturalism would appear only, say, in the distinction between Catalan literature and Castilian literature, or perhaps, I don't know how much Basque literature there is, really, so... I think that might be a little bewildering to a Spanish reader if they did not understand how bad the situation is here. The situation really is very bad here.

JAG: Well, this book follows the line of the others in two ways: in its content, that it follows your line of research, and also in the criticism it has followed, as in the others. But in this one it seems you were more open, in the sense that you didn't worry what others might think when you use expressions such as "The School of Resentment"... unless you were trying to be provocative...

HB: Well, I explain what the School of Resentment is. It's a six-headed beast. The six heads of the beast are: they call themselves feminists, they call themselves Marxists, they call themselves New Historicists, which means disciples of Foucault, they call themselves Lacanians, disciples of Lacan, deconstructionists, disciples of Derrida, and finally, you know, semioticians. I think the six-headed apocalyptic beast has ruined the very idea that any writer in any language could be preferred to any other writer on the basis of greater aesthetic eminence. That is now denounced as a mystification and a mask, for social, economic, and political exploitation. But of course, the grim effect upon this is double: on the one hand, this movement, which is always talking rather tediously about what it calls political responsibilities of the critic, has in fact turned the United States against the universities and colleges, has helped elect a neo-fascist Republican congress, because it's this School of Resentment that has given rise to the hideous notion of political correctness, and there has been a national backlash against this, against affirmative action (as it is called), against multiculturalism, against political correctness, and the universities are going to pay a very high price for this.

But that interests me less, even though I think it's very unfortunate socially and politically speaking... that interests me much less than the fact that the ability to read closely and well is being destroyed in the United States. It was already in trouble because of visual technology, because of the computer, the television set, the cinema, and so forth. 
Reading is, after all, not something that directs itself to the eye, but to the inner ear, and if you have a culture that turns against the inner ear, it's going to be very difficult for reading in the deeper sense, particularly of poetry or of difficult prose, to survive. And indeed, serious poetry, first-class poetry, is being less and less read and studied in the United States. There is a serious breakdown in literary standards in the United States and Great Britain.

The United States is now so much the leading world power, and even though the so-called culture that it exports is mostly the culture of hamburgers and blue jeans and this hideous non-music called rock (horrible stuff which has blasted the eardrums apart), in some sense, since also the English language has become the lingua franca, replacing French, with only Spanish really as a rival, it's very curious. I'm not sure you can destroy all aesthetic standards in the United States, particularly in the study of literature, and it not be felt sooner or later in Madrid, or in Rome, or in Berlin.

JAG: To finish with this question, how would you feel if somebody considered you as belonging to "The School of Nostalgia"?

HB: My book argues as much against what could be called "The School of Nostalgia," but I don't call them that (our right-wing, or moralistic, or Christianizing critics). I've gotten more nasty reviews in right-wing publications even than in fashionable left-wing publications. I say right at the beginning of the book that my enemies are not only the School of Resentment, but are what you just named, the School of Nostalgia, the people who feel that the Western Canon is justified, and that its function is to inculcate democratic ideals or moral sanctions or traditional Christianity or middle class morality or whatever you want to call it. No... first of all I'm not a school; I am absolutely an eccentric and isolated individual. Even in my own university I am a non-department of one: I have no followers, no disciples, no allies, no critical cousins.

JAG: I remember you telling me sometime ago that you were a Professor of Nothing.

HB: Yes, yes: I regard myself as the Sterling Professor of Nothing, both here and at NYU [New York University]. No, one cannot speak of the School of Nostalgia, nor I think do I indulge in nostalgia. The last Western writer who seems to me incontrovertably canonical was Samuel Beckett. I don't know that a high regard for Samuel Beckett makes one part of a school of nostalgia. If you asked me what living writer is likeliest to be canonical I would probably have to say it would have to be [Gabriel] García Márquez.

JAG: I'd like to talk about that.

HB: Yes, there's no living...well, we have Thomas Pynchon in the United States. I suspect that Pynchon is going to be a canonical author. But no, I don't think I am nostalgic. You know, the heart of my book (I think this has not been understood)...I intend to in fact, when I finish writing a book called Omens of Millennium: Angels, Dreams, Resurrection, and Gnosis, which I'm writing for the moment, which is a religious book, as The American Religion and The Book of J was...I hope to devote three or four years of very hard writing to writing what I hope will be my magnum opus, which will be a huge book called Shakespeare and Originality, and, which will be an attempt to revive the study of character in Shakespeare, and which will be a commentary really on every major and every important minor character in Shakespeare's plays, because I think Shakespeare 
invents literary character as we know it. In some sense this book, on the Western Canon, is a prolegomenon to a study of Shakespeare and originality, because, as I say a hundred times in this book, Shakespeare is the Western Canon. I mean, one also says that Shakespeare and Dante and Cervantes and Tolstoy are the Western Canon, but above all else Shakespeare is the Western Canon. I mean, if Shakespeare does not manifest what it means to have supreme aesthetic value, then indeed there is no such thing as aesthetic value, which of course I don't believe for a second.

JAG: Ezra Pound at a certain point said that the history of literature was the history of about ten writers. You've taken it to one, plus twenty-five.

HB: Well, not really. I do not say that these are the twenty-six best writers, something which was widely misunderstood, even though I made very clear at the beginning of the book [...] there is one, plus the others. I don't think Pound would have dared disagree with that. James Joyce was once asked by his friend Frank Budgen, you know, the author of The Making of "Ulysses," was asked by him the traditional "desert island" question: if you were on a desert island and you could take only one book, what would it be? And Joyce hesitated (I talk about this in the book), and said, "I might want to take Dante, but I would have to take Shakespeare, because the Englishman is richer." And, I think that's all you have to say. I mean, the Western writer, forgetting the ancients -I am not talking about Homer, or Plato, or Sophocles, or Virgil, or the Bible- but the Western writer is Shakespeare, and after that the Western writer is Dante, and Cervantes, and Chaucer, and six or seven others. I mean, in that sense, Pound is probably right, even if we wouldn't necessarily agree on the same ten. I suppose he would've put a Provençal poet or two in there. Bertrand de Born or someone.

There is some sense in which, if you take the period from Dante to the present (which is all I tried to do in this book, forget that list), there is some sense in which, if you take the Aristocratic Age, and the Democratic Age, and the Chaotic Age, which is ebbing out now, in which in some sense there are about ten or twelve writers: I mean, Shakespeare, Dante, Chaucer, Montaigne, Cervantes, and just a handful of others...Tolstoy, Proust.

JAG: Goethe.

HB: Joyce. Goethe? Yes. There are about maybe twelve or thirteen who really are universal authors. But Shakespeare's different from the others, it seems to me, different even from Cervantes, who is his closest rival after Dante.

JAG: Okay. The Aristocratic Period is dominated by Shakespeare; the Democratic by Whitman.

HB: Well, in a sense, yes.

JAG: In a sense. And the Chaotic, though you recognize Kafka as the heart of the period, by Joyce.

HB: Well, Joyce or Proust, or Freud, I don't know. I mean, they're all equally great figures. Freud for me is basically, you know, an aesthetic author, though he would have been very furious if I had said so. If you were going to talk about the twentieth century, the one possible rival of Joyce is certainly Marcel Proust. I mean, you could make a very considerable argument that In Search of Lost Time is as large a monument as Ulysses and Finnegans Wake. I don't think there's a third who competes with those two aesthetically. In the nineteenth century, one is thinking more, much as I love Whitman, one 
is thinking more of Whitman's influence perhaps than of Whitman himself. If I had to think of a single nineteenth century author who is the largest, I suppose it would have to be Tolstoy.

JAG: Now, the question concerning this is, don't you consider Anglo-Saxon literature as overwhelming? In the three periods, there were three Anglo-Saxon writers at the center, how about a Spanish or an Italian or a Russian writer?

HB: Well, but as a matter of fact I don't think of Shakespeare as an English writer, because he is universal. He has been translated into every language; his plays are performed in every language and I don't think it makes any sense any more to think of him as being any more an English writer than he is, say, a German writer or an Italian writer. And he is so universal. I can't really think of Cervantes as primarily a Spanish writer, or of Dante as primarily an Italian writer. As for Whitman, I haven't agreed with you: I don't think Whitman is the dominant figure of the Democratic Age. He happens to be a democrat, that's why you think of him, but, if I had to look at a single writer of overwhelming aesthetic power in the nineteenth century, I could not legitimately argue [for] Whitman: I think Wordsworth is a greater poet than Whitman. Victor Hugo, whom I don't write about in the book, may be as large a figure as Whitman. Flaubert may be as large a figure as Whitman. There just wasn't room...

I don't think the book has an Anglo-Saxon bias. Besides, Joyce is not an Anglo-Saxon: he writes in English, but he writes it like a foreign language: he is a Celt. He is a Catholic, though he doesn't believe in Catholicism, he is raised as a Catholic Irishman. He is Celt, and not, not Anglo-Saxon. That's why he says rather bitterly to Frank Budgen, "I would have to take the Englishman," meaning Shakespeare. Who but Joyce would have referred to Shakespeare as "the Englishman." Besides, I mean, what is Beckett? All of the really important work is written in French, except for Krapp's Last Tape at the end and Murphy at the beginning, but everything else is written in French. And then usually it's translated into English by Beckett. You can call the prose trilogy of Malloy and Malone and so on... you can't call the major plays, especially Endgame...are they French works or English works? It's written by an Irishman, whose French is at least as good as his English. So I think these distinctions break down.

For a long time, until he died, Beckett was certainly the best writer alive. And besides, you know, what do these things mean? Borges, whom I write about, writes in Spanish, but starts in English. He learned English when he was a child. Pessoa learned English as a child, and wrote poems in English, as Borges wrote prose in English. It's very difficult to know. I don't think there's an Anglo-Saxon bias in the book. I myself am not Anglo-Saxon; I'm Jewish. Maybe you can see if there's a Jewish bias in the book, I don't know.

JAG: In other works you recognize the influence of the Greek and Latin writers on subsequent authors. But here they're not mentioned so much as before. Why?

HB: I was thinking about my readers. I provide them with absolutely no guidance on Homer, no guidance on Virgil, very little, almost nothing, about the Bible, nothing about medieval literature before Dante, nothing about Saint Augustine. It just seemed to me that I had not earned the right. I mean, look, the important thing for me about the book... I have tried to learn now throughout my life, how to write in a fashion which would 
not vulgarize what I was trying to say, but would make me more accessible to what I would think of, following my great hero Doctor Samuel Johnson, as the common reader. And that necessarily involves trying to write in a less learned fashion. And I think of the books that I've written so far, this is probably the least opaque and the most accessible, even though I realize that there are opacities in it, and there are many things in it which are not immediately accessible to a common reader.

One still hopes, you know... one's critical hero is Doctor Samuel Johnson, who wrote for the common, educated reader -we don't have a common educated reader anymore, whether in Spain or the United States. We just don't. This is the age of visual technology. So I made a deliberate attempt not to use classical references. I did not, for instance, in talking about Joyce, I talked about Joyce only in relation to Shakespeare. I deliberately excluded the whole question of Homer. In Dante, I almost deliberately excluded the relationship both to Virgil and to the whole question of Saint Augustine. With Cervantes, I had to deliberately exclude the relationship to what, after all, the Don Quixote satirizes, what comes before him. It was a deliberate restriction that I placed upon myself. I did not feel, for instance, in talking about Goethe, the second part of Faust, which so clearly is a bacchanalia on classical themes, as in the classical Walpurgis Nacht, I did not feel that I had a right to talk about Aristophenes, or even about Horace. I just felt that I had to exclude these things... I mean when I realized that for reasons of length I had to exclude what Vico calls the Theocratic Age, then I passed a limitation upon myself and I said, well, I will try to give literary references only from Dante to the present day. It produces beyond a doubt considerable lacunae, as for instance in the case of Joyce.

And the book starts with the pretext, the false assumption, which it realizes and says is a false assumption, that Western literature begins with Dante. Western literature obviously doesn't begin with Dante; Western literature begins with Homer, and the Bible. But in this book, which is limited, it begins with Dante. So I didn't feel I had any references I could give before Dante. Thus, when I got to Chaucer, for instance, I only mentioned Dante, and Boccaccio, even though in fact, Chaucer has a very complex relationship to classical literature.

JAG: You of course praise Cervantes, but it's only to point him out as a third place - Cervantes to you is the only possible peer of Dante and Shakespeare... isn't it relegating him to a third place?

HB: I think that if you were to speak of the major writers from Dante to the present day. Shakespeare, Dante, and Cervantes...

JAG: And why not Cervantes, Shakespeare, and Dante? Especially considering that the literary genre par excellence in the nineteenth and twentieth century is the novel.

HB: You could well, yes, you could well argue that since Cervantes, in the deepest sense, is the transition from the romance to the novel and is also the inventor of literary irony, even in the Kafkian sense, as I point out. But you know, Shakespeare's one advantage over Cervantes is the dramatic medium, since Shakespeare in fact is playing on all the stages of the world. And somehow Japanese Shakespeare remains Shakespeare, even though Cervantes is read all over the world and has an incalculable influence. But you know, it doesn't really matter. I mean, I repeat what I said: my favorite sentence of the book is, if multiculturalism meant Cervantes, then I would not protest. I would be 
perfectly happy to substitute Cervantes for Shakespeare. The order of achievement is exactly comparable. I would add a fourth figure, greater even than Tolstoy, Chaucer. Chaucer is a writer as strong as Cervantes, as strong as Dante, as inexhaustible as Shakespeare. There are very few such writers. You might want to argue that Rabelais, whom I don't write about, is such a writer. I'm not sure whether he is or is not, but you could make an argument for it.

JAG: Of course we can always make arguments in literature. For example, you've just mentioned that Shakespeare invents the literary character. Somehow that could be said as well of Cervantes.

HB: No, no, no, what I said was a literary character in the sense of dramatic representation. Cervantes, after all, was a dismal failure as a writer for the theater, which he blamed on Lope de Vega, of course, and gets his revenge, I think, by showing Lope as Don Pedro, the master of the puppet show, the trickster, and so on. I think I say in the book that it's very difficult to choose between Falstaff, Hamlet, Sancho Panza, and the Don [Quixote] as the supreme characters...and the Wife of Bath, and the Pardoner in Chaucer. And Dante the pilgrim, himself. It would be very difficult to choose between them in the order of literary representation.

Certainly if you set Dante aside, if you just go from the Renaissance to the present day, there is no third author comparable to Cervantes and Shakespeare. And if somebody were going to argue with me and say Cervantes is as great a writer as Shakespeare, I could not question it. The single book, the book, as Herman Melville said, the book above all books -I mean Shakespeare's not a single book; Shakespeare wrote thirty-eight plays, though Cervantes wrote The Exemplary Tales, which are very magnificent-in the end, the single book in Western literature after the Bible, as Unamuno says, is the Don [Quixote], beyond any question. I always keep a copy of it in English translation literally at my right hand. I have just reached down and touched it. Tucked away there.

JAG: You've just mentioned Unamuno, and it seems you really admire him.

HB: Oh, I love Unamuno. Unamuno is a great writer, and a great critic. As I say in the book, my chapter on Cervantes is entirely in the spirit of Unamuno. I follow Unamuno at every point. I don't know how many references there are...

JAG: At every paragraph.

HB: Yes, at every point he's guiding me in what I'm saying. I'm in love with that book: Our Lord Don Quixote is a very great book. And Unamuno's Exemplary Tales are almost as interesting as Cervantes'. They're quite remarkable. Have you read them? Astonishing, astonishing. The three Exemplary Tales that he writes, in imitation of Cervantes, one of them contains the very great sentence (which all feminists hate): "All women are one woman," which is very Unamuno-esque. Is Unamuno still highly regarded in Spain, or is he neglected?

JAG: Yes, he is still highly regarded.

HB: Oh yes? Well. Remarkable intellect... Ortega is, of course, a very considerable literary intellectual. A very powerful literary intellectual. But Unamuno has that touch of madness, you know, that touch of the sublime, that touch of the fantastic [...].

JAG: Okay, there is one name in this conversation that you've named only very briefly, and it's Goethe. 
HB: Oh well, my favorite. If I had to vote for what I think is the best chapter in the book, I would say that the best and funniest chapter in the book is the chapter on the second part of Faust, which I've had some response to in Germany, but very little response to in the United States, or Great Britain, or abroad. I think that's a hilarious chapter, on the most outrageous piece of canonical work.

JAG: But what happens with the other Romantics? What happens with Byron, Shelley, Keats?

HB: Well, there isn't room! Wordsworth is there and Goethe is there. But there is no room for Byron, Shelley, and Keats. Well, what am I to do? It's like people complaining, why is Flaubert not there? And I have a friend, a former student, who teaches Renaissance literature, who said he was completely shocked that there isn't a chapter on Tasso. I mean, what can one say? Rabelais isn't there. Ariosto isn't there. Racine isn't there. Baudelaire isn't there. I mean, Henry James isn't there. Herman Melville isn't there. Ah, what can one do? I had thought I was going to write a book on fifty writers; I discovered it was impossible. So I wound up with just half that number.

The book was unwritable, as I discovered. And, in the end, Paul Valéry has, as you know, a very great remark: Paul Valéry says, and I've quoted this in many places, that no poem is ever finished, it is merely abandoned. And this book was never finished; I had to abandon it, because I didn't know what else to do. I didn't know what one did. I felt very badly...my favorite writer in Spanish, after Cervantes, is Calderón. I wanted very much to write a chapter on Calderón, if only so as to make him better known in this country. I just didn't have space for it.

And if I had to talk about the great poet of the twentieth century, even though Neruda is very powerful at his best, and I have great passion for Pessoa; obviously Neruda and Pessoa are not as good poets as Luis Cernuda was. Cernuda's a very great poet. Let alone [García] Lorca. And, as I said to you before, the greatest poets of the century (Wallace Stevens, Lorca, Hart Crane, Paul Valéry, Paul Celan, Georg Trakl, Rainer Maria Rilke, Eugenio Montale) are not in that book. They're just not in that book, and it's too bad. But you can only do so much in one book.

JAG: And of course, you have to choose, and to choose means to reject.

HB: Well, to choose doesn't so much mean to reject, but you need to cover the major national literatures.

JAG: This is the point: Why Dickens, and not Henry James? And why Tolstoy and not the one you have not mentioned...

HB: Dostoevsky?

JAG: Of course!

HB: Well, Tolstoy may be the greatest writer in the Russian language, but the Russians themselves think that the center of their canon, the way Goethe is the center of a canon or Cervantes is the center of a canon, or Dante, is Pushkin. Pushkin is absent from the book; Dostoevsky is absent from the book; Chekhov, as great a dramatist in his way as Molière or Ibsen. Chekhov is not in the book. There was a real problem. Had I been able to write about fifty writers, Flaubert would have been in the book, and Dostoevsky would have been in the book, and Henry James would have been in the book. Indeed my 
personal favorites among Western writers, are mostly not in the book. Emerson is not in the book.

JAG: Yes, but what I mean is, if you have to choose one...

HB: If you have to choose one Russian writer, and I had only space for one, the three I considered were Pushkin, Tolstoy, and Dostoevsky, and, in the end, it has to be Tolstoy. And I didn't want to choose War and Peace or Anna Karenina, because I wanted an instance where his aesthetic sensibility overwhelms his moral obsessions, and his anti-Shakespeareanism, and he writes a powerfully Shakespearean, or even if you want to have it so, Cervantine, story, in the late story "Hadji Murad," which is pure storytelling, which is an aesthetic masterpiece, which is a very great piece of writing. It's the best story I've read in my life, as a story. Dostoevsky may or may not be more profoundly introspective than Tolstoy... he's certainly more Shakespearean than Tolstoy (he loved Shakespeare), and, as I remark several times, you wouldn't have Svidrigailov and Stavrogan, if you didn't have Iago, if you didn't have the Shakespearean hero-villains, if you didn't have Edmund in King Lear.

Nihilism is invented by Shakespeare, and Dostoevsky knows it. Indeed I would argue myself, and the right-wing critics in this country would be very angry at me for saying, they imply it very clearly: I think Shakespeare is a nihilist, ultimately, and that he is the greatest nihilistic writer, you know, in the West, and that ultimately our literature is nihilistic because of Shakespeare. As to whether Cervantes is ultimately nihilistic, I am not prepared to say. I think one could make an argument that perhaps he is, which is what Unamuno I think is secretly saying - he's always on the verge of saying, it's what Nietzsche says. They're not willing to cross over. Why is Nietzsche not in the book? Nietzsche and Emerson and Kierkegaard, those three writers, are far more important to me personally than Tolstoy is. They are much more important to me than, say, Montaigne or Molière are.

JAG: My question was why you chose those you did.

HB: One tries to choose writers who are exemplary. Thus for France, for instance, one has to leave out Rousseau, one has to leave out Balzac, who is my personal favorite. One has to leave out Victor Hugo, whose poetry I think is immensely underrated, for he was a great poet.

JAG: And then you overrate Dickens.

HB: Oh no. No, no, no. How can you overrate a writer of that fecundity and power? Dickens is as close to a novelist of the stature of a Cervantes that you can find in English. Dickens is the major novelist of the English language, surpassing Henry James, surpassing even George Eliot. But I wanted an instance of a canonical novel in the nineteenth century, and since I wasn't writing about Anna Karenina or War and Peace, or Dostoevsky, I had to ask myself, well, who are the exemplary novelists in the nineteenth century? Probably I should have taken one French and one English, but George Eliot and Dickens are at such extremes from one another... probably I should have left out George Eliot, and used Flaubert or Stendhal. But what could I do? I mean, it's very hard to choose, they're very hard to choose. You cannot exclude the arbitrary when you try to write a book called The Western Canon. Obviously you cannot write such a book, and leave out Shakespeare and Cervantes, and Dante, if you're going to start from Dante on. And you 
cannot leave out Proust. I didn't see how you could leave out Tolstoy, whereas you could leave out Dostoevsky, finally, if you had to choose. How can you leave Melville, who is in many ways the most powerful nineteenth century American writer, and if I had to vote for one American book, it would have to be Moby Dick, more even than Huckleberry Finn and Leaves of Grass: I would vote for Moby Dick, but, there just wasn't room.

JAG: That I understand, of course, and in your book you also did mention that one cannot read everything. But let's go to the next period, the Chaotic.

HB: The Chaotic Age, yes.

JAG: I think the novel is brilliantly represented, and nobody can say otherwise, I think.

HB: I have deliberately underrepresented the poets and dramatists of the age. The leading dramatist in the twentieth century is probably not Beckett, remarkable as it is, and is certainly not Brecht; it is probably Pirandello. Luigi Pirandello is probably more important in the history of the twentieth century drama than anyone else is.

JAG: I was about to ask you why poetry is not fully represented.

HB: Well, I happen to love poetry much more than I love the novel, but as it happens the audience for poetry is smaller in the twentieth century than it's ever been before, and though it is a great age, one would have a very hard time arguing that even a Valéry, and Rilke, and Trakl, and Wallace Stevens, and Montale, and Lorca, and Cernuda, and all the others, one would have a very hard time arguing that they were of the greatness of Joyce and Proust. But again, I have a real problem, which is space. If I had had to put in a single twentieth century poet, I don't know, it would have to be probably Yeats or Lorca, or Wallace Stevens, or Rilke. I don't know.

JAG: It seems you are not very fond of modernism in poetry.

HB: How can you say that? What do you mean by modernism? If modernism means Ezra Pound, no I'm not fond of Pound's poetry. If modernism means Eliot, even though I hold my nose, because I find Eliot loathsome, particularly his prose criticism, yes.

JAG: Yes, I meant exactly Eliot, Pound, and William Carlos Williams.

HB: Eliot is a great poet. William Carlos Williams at his best is a very good poet. Pound at his best is almost a great poet.

JAG: And you did not mention Lowell and Larkin...

HB: Lowell and Larkin are I think stuffed owls, you know. I think they're period pieces. But, it depends what you want to call modernism: Hart Crane and Lorca are modernist poets... Pessoa is a modernist poet.

JAG: Rubén Darío.

HB: Oh, yes, yes, he's an interesting poet. It's interesting that Nora Cartelli, in her article in one of the Spanish newspapers criticized me for bringing him in, saying that she didn't think he was first-rate; but he's a precursor figure for the South American poets in general, or Latin American poets if we have to call them that. I put in Neruda because he's representative. Vallejo I think is probably a more powerful poet.

It's very difficult to say. You could argue that the poet of the twentieth century is Paul Valéry, and that if one has a chapter on Proust, one should have a chapter on Valéry. It's hopeless. You know, there's just so much space. The book in that sense was unwritable. But I thought it was important to write the book if only so as to start the argument again. 
Look, if there is value in the book, and I would like to think there is value in the book, it can only be two things in the end: on the one hand to insist that there is such a thing as the aesthetic, and that it stands absolutely separate from the economic, the social, and the political.

JAG: And that's why after Beckett, and I quote you, everything is "fresh technologies for distraction?"

HB: Yes, yes. Well, what I was saying was that part of the enormous relevance of Thomas Pynchon, is that that is very much at the center of his concern. I was saying that I am rather surprised that both the Latin American novelists and poets, and Spanish and Catalan novelists and poets, seem less concerned with this question of the technological nightmare, since after all, particularly since the end of the Franco regime, Spain has been very rapidly modernized, and visual technology is going to be as large a problem for the aesthetic in Spain as it is now in the United States.

JAG: The aesthetic component in literature is of main importance to your criticism. But could it be understood as if you were jailing the writer in his ivory tower?

HB: Pooh. Absolute pooh, I am not talking about that at all. I'm not talking about art for art's sake, which is a phrase of Walter Pater's that has been very much misunderstood and mangled anyway. What I am talking about is the fact that some writers are better than other writers, that's all that I'm saying, and that the reason why some writers are better than other writers has nothing to do with their political, social, or economic relevance. That's all I'm saying; I'm not talking about ivory towers at all.

You can't jail writers in ivory towers, obviously. I mean, the outstanding novel in the twentieth century is Proust's In Search of Lost Time, and it is a mirror of everything that has been happening in France in the era of Dreyfus. Nevertheless, the great insight of Proust, the great achievement of his last book, is a kind of aesthetic clarification which is finally a kind of salvation, not so very different from Unamuno's reading of Cervantes, I must say. What Unamuno is saying, as I understand him, is that the religion of Spain should cease to be Catholic and should become that of Don Quixote - which is a shocking and brilliant idea. In the same way, I think Proust, who is descended from the aesthetes by way of Ruskin, is essentially an aesthetic sensibility: I'm not trying to lock Proust in any ivory tower; I'm not trying to lock Joyce in any ivory tower. I really am simply reminding us that some books are better than others for intrinsic, rather than extrinsic, reasons, and that if we lose sight of that, we may as well stop reading. And if you can say, well, that's so commonplace, why do you bother to say it? Alas, alas, alas, I wish it were still commonplace, particularly in the United States and Great Britain. But it isn't commonplace anymore. It's not commonplace at all.

JAG: We've been talking about writers, but let's have a question about the readers. Your approach, as opposed to that of Leslie Fiedler, who considers the readers the only ones entitled to write a canon, in the sense that...

HB: I think Leslie, who is an old friend, is quite wrong, I think. I even say at one point... I was thinking of his phrase, "opening up the canon." I'm saying that's a redundant phrase, an unnecessary phrase, because the canon is never closed. The canon, and ultimately this is the second reason I wrote my book: my book is the logical endpoint for 
my study of what I would call the idea of influence in Western literature. My book is The Anxiety of Influence written on a large scale.

\section{JAG: You mean The Western Canon.}

HB: Yes. I mean, in some sense it's about the influence of Dante, and the influence of Shakespeare, and the influence of Cervantes.

JAG: Shakespeare, according to you, had a kind of anti-Semitic feeling.

HB: I think that beyond any question, The Merchant of Venice is an anti-Semitic play, alas. And in that sense, Shakespeare was very much of his own time in England.

JAG: I mentioned it as a kind of introduction for my next question. In the Chaotic Period list, and I would like to comment on the list at the end, you name twelve works written in Yiddish, and only thirteen written in Spain (I'm not saying in Spanish, in Spain). Does it have anything to do with your Jewish origin, and do you think that Yiddish and Spanish are balanced?

HB: I hadn't thought of it in that sense... I undoubtedly, I mean, Yiddish is my native language: it is what I spoke as a child, it undoubtedly reflects the fact that I know Yiddish literature better than I know Spanish literature. I think in Yiddish, when I get tired. I dream in Yiddish. When I think of my parents, I think in Yiddish. Spanish for me is an acquired language, which I can read but I cannot speak. I wish I could speak Spanish. I don't think that's a fair question. I say we're now in that area, primarily, of my list, which is twentieth century, where I call it a canonical prophecy, unlike the other three lists, and I begin by saying canonical prophecy is a mug's game. I make very clear that the list is provisional, that it is personal, that it is provocative, that it's suggestive, that it's subject to revision, and that it cannot possibly be right. No one can really tell until fifty years at least have passed by, whether something is a period piece or not. It is not possible. It is not possible... I was thinking primarily of readers in the United States and other English-speaking countries.

JAG: Right.

HB: What do you do with an extremely difficult writer, where your Spanish would have to be far better than mine is to make any sense of him, and where there is no adequate English translation at this time? That simply is a limitation that I have to accept. He may well be, he probably is as great a writer as you tell me he is, but I have no way of knowing this, because my Spanish is not good enough, and we need some translator like Samuel Putnam, who did such a wonderful translation of Cervantes into English, who is dead now, of course. We need some translator of genius to come along and render him into English.

JAG: Well, somehow you've answered part of my next question. I do not pretend to make a case of the Spanish importance in your book. I do recognize that one cannot read everything. I can admit that you don't include the Arcipreste de Hita, Santa Teresa, Don Juan Manuel, Garcilaso de la Vega, Pedro Salinas... but to me, and it has nothing to do with me being Spanish, it's difficult to understand why Valle Inclán is not included.

HB: Yes, no, I can understand that, but it would have been dishonest for me to include him, because the Spanish is too difficult for me, and I have not found an adequate English translation, which could suggest what his aesthetic qualities are, so I would have to take it strictly on faith. And that would be dishonest. One could argue one has left out many figures in Spanish literature. Had my book been written by a Spaniard, there would 
be fewer works of English and American literature, as well as Yiddish literature, and many more of Spanish literature, of course. So there is to some extent now a universal canon, and a world canon, and a Western canon -in the end the canon is a national idea, and probably can never cease to be, to some extent, a national idea. It happens that I can read Catalan poetry because I studied Provençal, and...

JAG: Is that the reason why you include a chapter on Catalan?

HB: Yes, because, you know, Catalan poetry is in some ways easier for me than Castilian poetry, because even though I studied Spanish, I probably did not study it as well as I studied Provençal. And it is surprising how close Catalan poetry is to Provençal. Spanish poetry is very difficult for me, although, you know, with the help of good translations and good commentaries...

JAG: For example, Góngora; you've shown me his Soledades...

HB: Góngora is a poet who I've come to appreciate; Quevedo is a poet I find much more difficult. Very difficult;

JAG: Even more than Góngora?

HB: Yes, well, because the commentaries and concordances are not as good. I've had great trouble penetrating him. Calderón I can appreciate much better than I can Lope de Vega; I find his Spanish for some reason more difficult, though my friends María Rosa Medical and Roberto González Echevarría, tell me that I'm mistaken, that Calderón's Spanish is actually more difficult than Lope de Vega's. I wonder why I've had that difficulty. I guess I'm just more sympathetic to it than I am to Lope de Vega, who is prodigious, I must say: his energy is amazing - clearly has great verbal power, but has never been the influence on English and German poetry as Calderón. Calderón has an immense influence on Shelley, an immense influence on Goethe. It's very hard to conceive either part of Faust without Calderón. [It's] very difficult to think of Shelley without Calderón...very difficult to think of [Hugo] von Hofmannsthal. There, there's someone...I greatly prefer von Hofmannsthal as a playwright and poet to many of the people that I wrote about in the twentieth century. But I just did not have space for him. And he is pure, he is pure Calderón; he's inconceivable without Calderón, he is a disciple of Calderón.

JAG: Okay, but let's take Lorca, whom I know you really appreciate...

HB: Oh, I love Lorca's poetry.

JAG: ... but you mention him just once in the book.

HB: (Sighs) Ah. I don't think I mention Cernuda at all, and I love Cernuda's poetry. What can one do? I love Hart Crane's poetry more than any poet in the twentieth century; I doubt that he's mentioned in the book. I mean, what can one do? It's not meant to be a purely personal book, though it is partly, necessarily personal and arbitrary. To that extent I think the book is probably a failure. That is to say that, as a total impression, it falls short of what I wanted to do. But I discovered that what I wanted to do was beyond my powers - perhaps beyond the powers of any single national critic. I don't know. I don't know. I'm not sure that even Wallace Stevens is as great a poet as Cernuda, at least in terms of the traditional highest sublime. Cernuda is a very great poet, almost unknown in the United States. But there is one good translation into English by a man named Reginald Gibbons, I believe, which I listed.

JAG: And which one would you praise more, Cernuda or Lorca? 
HB: Well, Lorca is a greater genius, beyond a doubt. He's more original and fecund, and influences Cernuda. But Cernuda had more time to mature, of course... and of course Lorca is a dramatist; Cernuda is not a dramatist. He meditates the lyrical sublime almost in the old sense, the Pindaric sense. He is, I think, shockingly underrated in contemporary Spanish criticism.

JAG: Unfortunatly, he is.

HB: I mean, there are poets who are praised more from the great generation [Generation of 27]. There's much more interest in contemporary Spain than in Cernuda. I think you could argue that after Lorca, the great poetic genius of the twentieth century in Spanish is Cernuda, surpassing the Latin American poets. Certainly surpassing Pessoa. Pessoa is a wonderful, crazy poet, is an astonishing literary phenomenon, but I don't think that in the end he is as pure a poet as Cernuda.

JAG: Before the interview you told me that if you had a second edition, you would take off the lists at the end. Has it been so controversial?

HB: Well, there is already a second edition. I mean if I lived long enough and I got the book back from the publisher, which I never will...ideally, if I could get the book back again (and I can't), I would probably leave off the first and the last chapters, which are argumentative, and which are sure to be period pieces someday, and I would omit the list, particularly the fourth part of that list, because I think these things are distractions, and I would use this space instead for writing about more authors - maybe I would write about Lorca and Cernuda. I think I regret now writing about Neruda. But you know it was very curious what happened. I wanted to write about Whitman and the Latin Americans, and originally, in fact, that was going to be a chapter about Octavio Paz, Pablo Neruda, and Borges [...]. I wasn't going to write about Pessoa at all, even though he fascinates me, probably because of his strange affinities with Hart Crane, though the two poets never heard of each other -though Hart Crane also has tremendous affinities with Lorca, and I think they met once, Lorca and Crane.

JAG: While they were in New York.

HB: Yes, though I think the least impressive of Lorca's works is Poet in New York. I think that is just not vintage Lorca: it doesn't compare to the great...

JAG: Romancero gitano.

HB: Yes, yes. It doesn't compare to Yerma, or Blood Wedding, or the other great... It doesn't compare to that great "Sleepwalker's Ballad," which is a great poem.

JAG: It's not the sublime Lorca.

HB: That kind of thing Hart Crane does better, much better, I think. The surrealistic Lorca is not Lorca at his best. But I wanted to write about... it's a book about influence, and after addressing the question of Dante's influence and Shakespeare's influence I wanted to talk about Whitman's influence, and that got me into Neruda. It could have gotten me into César Vallejo, as you say. But I would in the end read a great deal of Neruda: some of it is very wonderful; some of it is very powerful; some of it not. And while Borges fascinates me, he is rather repetitious.

JAG: Regarding South American literature you talk about Neruda, and to many people Borges, and García Márquez are much more powerful. 
HB: Are larger figures. Well, I wanted a South American poet, in relation to Whitman, so I came up with Neruda. I could have chosen Octavio Paz, but I don't think he is primarily a poet: he's a better essayist than he is a poet. Borges is a better storyteller, and a better essayist, than he is a poet. Even though the Spanish American novelists are, I think, more powerful than the Spanish novelists in the twentieth century, setting aside Valle Inclán, I don't think that the Spanish-American poets, Neruda, Vallejo, and Guillén in Cuba, you know, the black Nicolás Guillén not the Spanish Guillén, I don't think they are as powerful as the great Spanish poets in the twentieth century. I think that Lorca, and Cernuda, and that fellow that has all those fantastic angels (my mind is a little tired at the moment)... [Rafael] Alberti [...] I think of the poets of the twentieth century, the one whom I would rank with García Lorca, and Cernuda, would be Rafael Alberti.

\section{JAG: Why Alberti?}

HB: For sheer originality, for that crazy humor, and those angels, don't you remember his angels? He has these weird angels, they're not like any other angels in literature: they're much more oppressive than the rather dull angels of Rilke. My friend Mark Strand did a very nice volume of selections from Rafael Alberti.

JAG: Would you prefer Alberti rather than Aleixandre?

HB: No, no. It's neck and neck. It's neck and neck. Those, those four are very difficult to choose between. I suppose Lorca, Cernuda, Aleixandre, and then Alberti. Alberti is still alive, is he?

JAG: Yes. Very much still alive.

HB: He must be... ninety years old.

JAG: Ninety-three.

HB: Ninety-three! He is the last survivor of the great generation.

JAG: It seems the tone of the book, somehow to me it's very pessimistic. And I'm going to quote: "We approach the second millennium expecting farther shadowing." Are we coming to another Theocratic Age?

HB: Theocratic Age? Well yes, that's what I say throughout the book. You know, you talked about people who don't like what I've done, saying that I want to put the poet back in an ivory tower. I haven't put myself in an ivory tower. What shadows my book prophetically, because when I wrote it, the Republicans had not triumphed in the last election, but I went around prophesying that they would - the Republican party has become a ghastly thing called the Christian Coalition, the American Fundamentalists of Ralph Reed and Pat Robertson and so on. I fear that the United States by the year 2000 will be a much more Theocratic country; that they will eat away at the Constitution, and that they will impose a religious censorship, and I don't know where that will end. On the one hand, you have a reactionary Catholic church: the Polish Pope [has] quite certainly packed the college of cardinals with very conservative people. There's not going to be any more Pope John. This Pope will be followed by popes even more reactionary.

JAG: Which Pope John are you referring to? John XXIII?

HB: Yes, yes, the one who brought about the Great Reform, John XXIII. There's not going to be any more Pope John XXIII. The Polish Pope, John Paul II, who was brought in as we know (because they murdered John Paul I. All my friends in Italy insist on that), has appointed extremely conservative cardinals all over the world: black ones, 
yellow ones, you know, all over. We're going to have a more and more theocratic Catholicism, which doesn't have much power in Spain, you know, having to do with reasons of Spanish history, because of its alliance with Franco and its oppressiveness before that. The United States is in real danger of becoming a theocracy. The Muslim world is increasingly dominated by the most terrible fanatics, both Shiites in Iran and Sunni elsewhere. And in a strange way, I think that what I call the School of Resentment are just as much theocrats of their kind of orthodoxy, as the right-wing in America are theocrats. I think political correctness is a theocratic notion. I think so-called multiculturalism is theocratic in its bias. I think the attempt to politicize criticism and overpoliticize literature is theocratic. I think aesthetic sensibilities are going to be more and more in a state of siege. I prophesy in the book that literary criticism, which is already dying in the universities of the English-speaking world, will die completely, that real literary study will end in the English-speaking world. Well, I believe so. It will be replaced...

JAG: That's extremely pessimistic.

HB: Well, it's happening all over the country and in England: cultural criticism, so-called, has crowded out literary criticism. People don't teach poetry. You don't have people reading John Donne or reading Góngora. You don't have people reading Edmund Spenser, you don't have people reading difficult poetry in any language. The very idea of difficulty has been deprecated. I think literary criticism will survive, but it will survive outside the universities, the way literature will survive outside the universities. I also think that technologically - virtual reality and the cyber-text- may do a great deal towards destroying literature. I think it's very, very hard for young people in the western world to read very deeply, because they haven't been taught patience, and you have to be very patient to read Wallace Stevens or to read Cernuda. You have to be very patient indeed. So I don't know... I feel pessimistic, I feel pessimistic. On the other hand, literature always survives, and literary criticism always survives, sometimes in strange forms. Maybe there's a lot of personal pessimism in it, you know: I am not, in many ways, the happiest of human beings, which I don't want to get into obviously for an interview.

JAG: Let's finish with a little joke.

HB: Yes, certainly.

JAG: What would you do if tomorrow there would be the certainty that the legend that Shakespeare never existed, became true?

HB: It wouldn't make the slightest difference. I sometimes tell my students that I've occasionally felt like arguing that Shakespeare is not a dead white European male, but that I wish that all of Shakespeare we could prove was written by a well-known prostitute of the time named Lucy Negro, who was an East Indian black or brown lady, Lucy Negro; and I wish we could prove she was the Dark Lady of the Sonnets, though she wasn't, and that she wrote all of Shakespeare, because it wouldn't make the slightest bit of difference. Freud wanted to say that the Earl of Oxford had written Shakespeare. Other people want to say that Sir Francis Bacon had written Shakespeare. This is all nonsense, but it doesn't make the slightest bit of difference because the plays are there. They happen to have been written by evidently, a very commonplace and colorless human being, with only a grammar school education, an apprentice actor of astonishing genius - but then, how can 
you predict human genius? Cervantes was a soldier... I don't know what scholars currently think, whether his family was New Christian or not, though I feel a shadow at times, as I read...

JAG: Cristiano viejo. Old Christian.

HB: Old Christian. Well, he obviously wants to be Old Christian because it isn't safe to be New Christian. But I don't know. At an ecclesiastical procession at one point... there are strange, dark moments in the book. Very strange moments. I don't quite know what to make of them. I mean there's his great fondness for the Celestina... by Fernando de Rojas. One of the greatest books ever written. I thought actually of writing about Rojas. I don't think there is a greater work in the Spanish language except for Cervantes, than the Celestina. A shocking book.

JAG: And El libro de buen amor by the Arcipreste de Hita?

HB: Yes, yes, I should have talked about that also, and listed it. What can one do? You know, one makes mistakes; there are errors of omission. I was surprised to be told that Saint Teresa was not there. I'm a great admirer of The Interior Castle: I thought that, as with Luis de León and Juan de la Cruz, I had put it in. You know I did the list entirely from memory.

JAG: Really?

HB: I have a very good memory, you know. But the reason why the list is in such a curious order, not chronological for instance, and so on, is because I thought the honest way to put it down was to rely upon memory. I have never for instance verified a quotation in my life. William Hazlitt once said if you can't quote it from memory, you have no right to quote it at all. I remember everything, and so I write it down that way. And so I just listed the authors whom I remembered. I didn't consult guide books or histories of literature. You know, this is a personal canon, this is what I remembered, but of course my memory, in at least a dozen cases, betrayed me. I can think of a dozen authors I would have included if I realized that I was leaving them out. At first, it surprised me to find that they were not there, but, what can you do? What can you do? We, all of us, are trapped; Wallace Stevens has a great passage of poetry in which he says: each of us condemned to be, himself or herself, that inescapable animal. That's how I would end. 